研究

\title{
高速度鋼粉末の金型による高圧成形
}

\author{
浅見 淳一涾，川原 正言的2 \\ 的東京都立工業技術センター金属部，テ115 北区西が丘3-13-10.

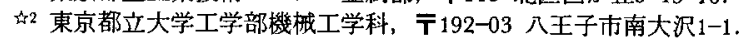

\section{High Pressure Compacting of High Speed Steel Powder by Using the Die Assembly}

\author{
Junichi Asami ${ }^{\natural 1}$ and Masanori Kawahara \\ th Metallurgical Dept., Tokyo Metropolitan Industrial Technology Center, 3-13-10 Nishigaoka Kita-ku, Tokyo \\ 115. \\ t2 Department of Mechanical Engineering, Tokyo Metropolitan University, 1-1 Minamiosawa, Hachioji 192-03.
}

Received December 12, 1994

Sufficient green strength can be attained for water atomized and annealed high speed steel powder with the M2 grade by use of conventional die pressing. In addition, this obtained green compact can be sintered to the full density by liquid-phase sintering. However, fine control of the sintering temperature is required for this type of eutectic sintering.

The high pressure compaction was tried to improve the sinterability on the solid-phase sintering. The two-step pressing method is applied to the high pressure compacting. High pressure up to $1470 \mathrm{MPa}$ can be attained by a special die assembly and apparatus. The sintered density reached to $7.4 \mathrm{~g} / \mathrm{cm}^{3}$ with very little shrinkage in dimension by $0.8 \%$. The radial crushing strength of sintered compacts increased in proportion to the compacting pressure.

These benefits in sinterabilty means that this is a more economic net shaping $\mathrm{P} / \mathrm{M}$ process for wear-resistant machine parts.

\section{1 緒言}

真空燒鈍を丹念に行った水アトマイズ高速度鋼粉末 は金型成形が可能でかつ良好であることと、液相焼結 により真密度となることを特徵 ${ }^{1-3)}$ とする。本研究で は前者に着目して形状付与および量産性などを考虑し， 本来工具素材である本粉末を機械部品等に適用するこ とを目的とした。ここで後者の焼結については素地と 炭化物の共晶液相を利用するため, 真空霧囲気中, $1500 K$ 付近の焼結温度で $\pm 2 K の$ 温度制御 ${ }^{3}$ が必要である. さらにこの適正温度は粉末中の炭素量に依存する("こ
とから、焼結操作上に困難さがある。そこで真密度を 目標とせず固相焼結での特性向上を検討した。すなわ ち，成形圧力を高めることによる高密度化の可能性を 調べた，成形方法としては，通常5 の2 倍以上の成形 圧力を使用するため，筆者らが行っている2 回成形法 ๘)ータ)を用いた。

\section{2 実跧方法}

原料粉末は水噴晸し真空娃鈍したSKH51相当の高速度 鋼粉末(M2)である. 粉末形状はFig. 1に示すように水ア 
Table 1 Chemical composition of M2 powder (mass\%).

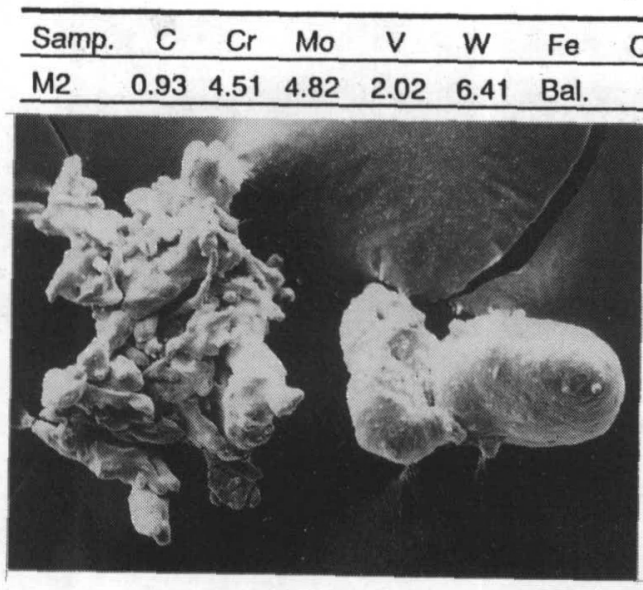

Fig. 1 SEM image of M2 powder. $\overline{25 \mu} \mathrm{m}$

トマイズ特有の不規則形状のむのと比較的球状の粒子 からなっている．今回，鉄系機械部品を想定している ことから比較のために純鉄粉 (300M)を使用した.これ らの特性をTable 1およびTable 2に示す。粒度分布は M2粉および300M粉ともほぼ同じで前者の方が微粉側が 多くなっている程度である，従って，金型への流動性 などの取扱い上の問題は無い.

成形方法 ${ }^{6}$ は，Fig. 2に示すように径の異なる超硬金 型を用い， 1 回目の成形は左の金型でハンドリングが 可能な最低圧 $294 \mathrm{MPa}$ で一定とし，軸受形状 ( $\phi 16 \times 8 \mathrm{~mm})$ に予備成形した．この圧粉体を径のわずか大きい右の 金型（ $\phi 16.4 \times 8 \mathrm{~mm})$ にて本成形した. 特に 2 回目の金 型は高圧用に設計したものである，成形圧力の範柬は 490 1372MPaで行った. 低圧力側では, 通常の 1 回目 だけの成形との比較も行った，潤滑はいずれもステア リン酸亜鉛のアセトン分散液を金型に塗布した、M2粉 圧粉体の焼結条件はこの粉末の固相域である1473Kを採 用し，保持時間 $3.6 \mathrm{ks}$ 一定とした. 霝囲気は真空 (1x $10^{-8} \mathrm{~Pa}$ )で行った. $300 \mathrm{M}$ 粉の場合は, 焼結温度 $1393 \mathrm{~K} て ゙$ 3. $6 \mathrm{ks}$ 一定で, 水素雾囲気中で行った.

\section{3 実験結果および考察}

\section{1 M 2 粉の焼結特性}

本実験の条件設定のためにM2粉の焼結温度と通常の 成形圧力範囲における寸法変化の関係をFig. 3に示す. 燒結温度1493Kまでは成形圧力に関係なくほぼ一定で低 く，かつ安定しているが，この温度を越えると大きな 収縮となる、焼結体としての形状を保持しているのは 焼結温度 $1513 K$ 付近が限度であった。ここで成形圧力
Table 2 Particle size distribution (mass\%).

\begin{tabular}{lrrrrrr}
\hline Mesh & +100 & +150 & +200 & +250 & +350 & -350 \\
\hline M2 & 0 & 9 & 19 & 10 & 19 & 43 \\
$300 M$ & 5 & 19 & 26 & 10 & 18 & 22 \\
\hline
\end{tabular}

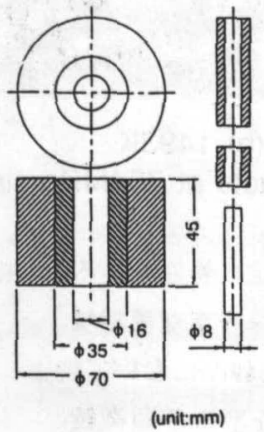

(a) First-compacting die

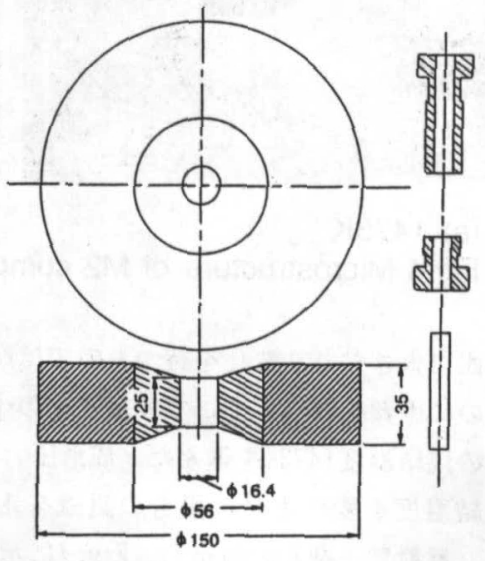

(b) Second-compacting die
Fig.2 Die assemblies used in two-step pressprocess.

392MPaのものでは寸法変化が高くでているが, 圧粉体 密度が低いためで, 炉中のわずかな温度分布により変 形や寸法のばらつきも観察された，この場合, 成形压 力784MPaの成形体で最高強度の得られる適正焼結にお ける寸法変化 ${ }^{2)}$ は 5 6\%である.このような狭い温度範

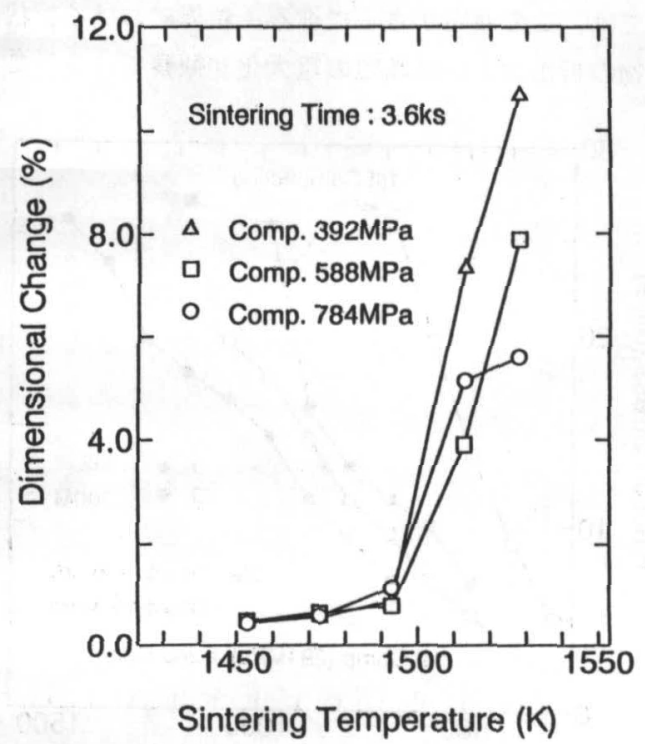

Fig.3 Relationship between sintering temperature and dimensional change on various compacting pressures. 


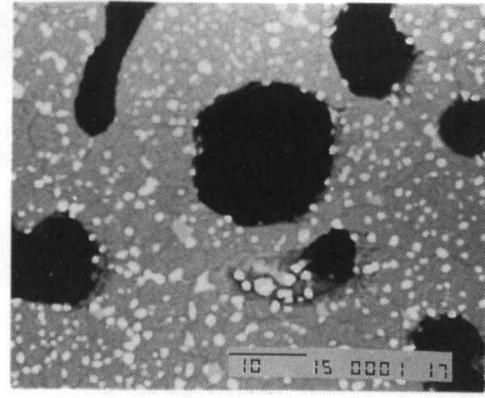

(a) $1473 \mathrm{~K}$

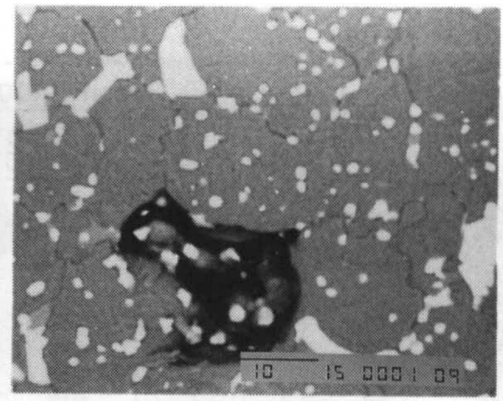

(b) $1493 \mathrm{~K}$

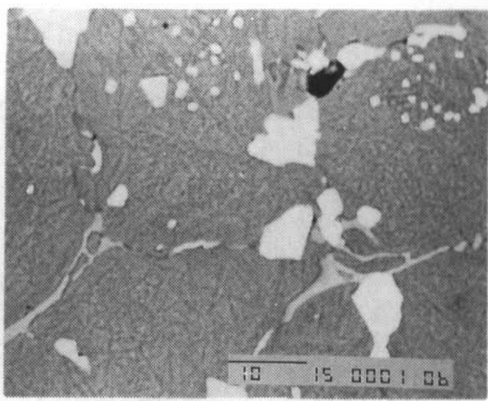

(c) $1503 \mathrm{~K}$

$\overline{10 \mu \mathrm{m}}$

Fig.4 Microstructure of $\mathrm{M} 2$ compacts at $784 \mathrm{MPa}$ sintered at various temperature.

囲で大きな寸法変化を持つものでは所定の特性を得る のに困難を伴う．そこで寸法変化の十分安定な固相域 の焼結温度1473Kを選んだ. 成形圧力784MPaにおいて焼 結温度を変化させた場合の組織を走查型電子顕微鏡 （反射電子像）で観察し，Fig.4に示す. 焼結温度 147 $3 K の$ 組織(a)は非常に微細な炭化物（白色部）が均一分 散している. また気孔 (黒色部) は存在しているが比 較的球状であることから, 固相焼結でも焼結性の良好 な粉末であることが分かる. 組織(b)では液相発生温度 直上のものと考えられ気孔はほとんど消滅しているが， ここに示すように一部に気孔の存在が認められ, 高速 度鋼のように硬質な材料では欠陥として強く強度に影 響を及ぼす.さらに粒内の炭化物の減少之粒界におけ る粗大炭化物の析出がすでに認められる. 組織(c)にお いては,この傾向がさらに進み，粒界における板状炭 化物の析出および結晶粒の粗大化が観察できる.ここ

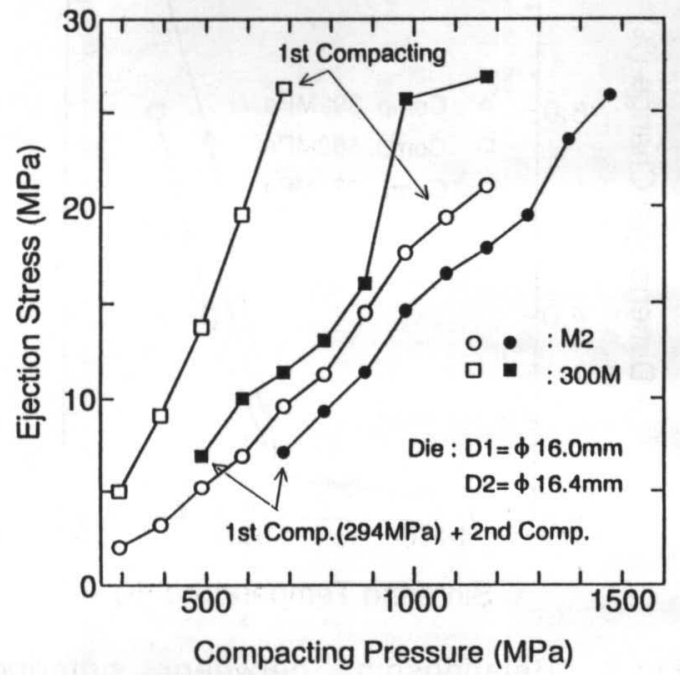

Fig. 5 Effect of compacting pressure on ejection stress of $300 \mathrm{M}$ and $\mathrm{M} 2$ powder.
でも組織の右上に収縮孔のような気孔も認められる． ここでは組織(a)のような原料粉末に近い組織で気孔を 小さく均一分散させるため高圧成形を行った．

\section{22 回成形における成形特性}

高圧成形を行う場合，金型への負担を少なくするた めにFig.2(b)のような金型を用いた．金型強度は超硬 部にテーパーをつけ，さらに焼締め量を増やす等の対 策を施した。ここで，高圧成形における成形粉末と金

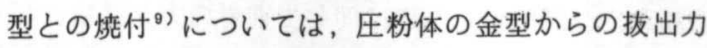
を目安とした、また、この対策としては 2 回成形用の 金型高さを最終圧粉体高さにかなり近づけられ，圧粉 体抜出しの際の摺動距離を短縮できる．そこで，焼付 状態が比較的明瞭亡なる純鉄粉を比較として抜出力と 成形圧力の関係をFig. 5に示す．まず，300M粉における 1 回成形と 2 回成形について, 前者では成形圧力に対 して比例的に抜出力の増加がある. 成形圧力 $686 \mathrm{MPa}$ 付 近で, 後述するような焼付が認められこれ以上の成形 は中断した，後者においては成形圧力 $882 \mathrm{MPa}$ (抜出力 16MPa）まで，1回成形より緩やかな傾きで增加し，成 形圧力980MPaにおいて 1 回成形の焼付状態と同じレベ ルまで急激に増加し，さらに高い成形圧力1176MPaにお いて, 抜出力は飽和している. 従って, 300M粉では抜 出力26MPa付近が最高値で, これ以上は焼付き部がせん 断して抜き出されるもの ${ }^{10)}$ と考える，2回成形では成 形圧力 $882 \mathrm{MPa}$ 付近で明かな抜出力の変化が認められる. 1 回成形では抜出力の増加が急なために現れなかった ものと考える.M2粉では両成形方法において, 成形圧 力の増加に対してほぼ同じ割合で抜出力の增加があり， いずれも300M粉のような焼付状態は高圧側においても 認めらず，高圧成形において良好な圧粉体を得易い粉 末2)である. 同じ成形圧では抜出力が2 3MPa程度， 2 回成形の方が小さく, 同レベルの抜出力では, 成形压 力に100MPa程度の差がある. 


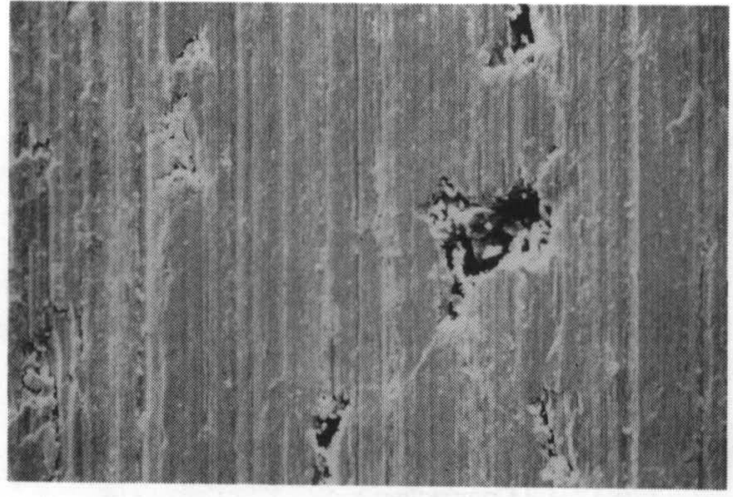

(a) Die side, 1st Comp.:686MPa, 300M

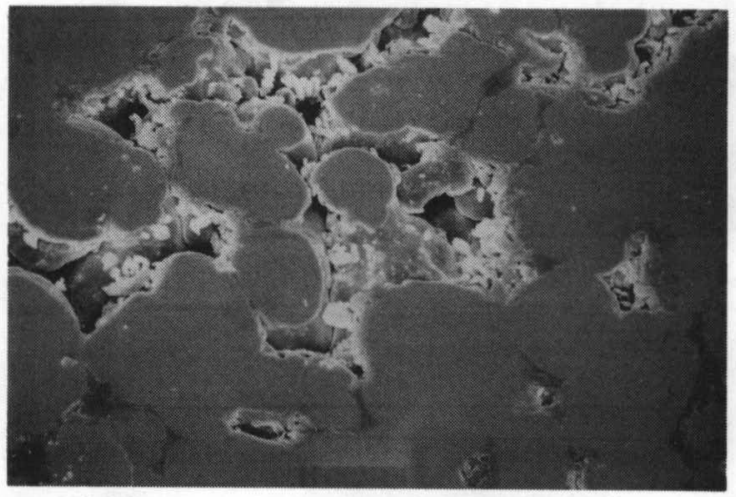

(c) Die side, 2nd Comp.:784MPa, 300M

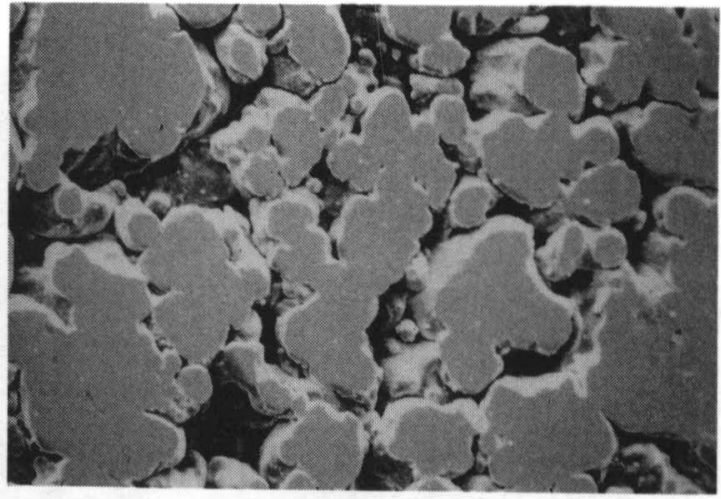

(b) Core side, 1st Comp.:686MPa, 300M

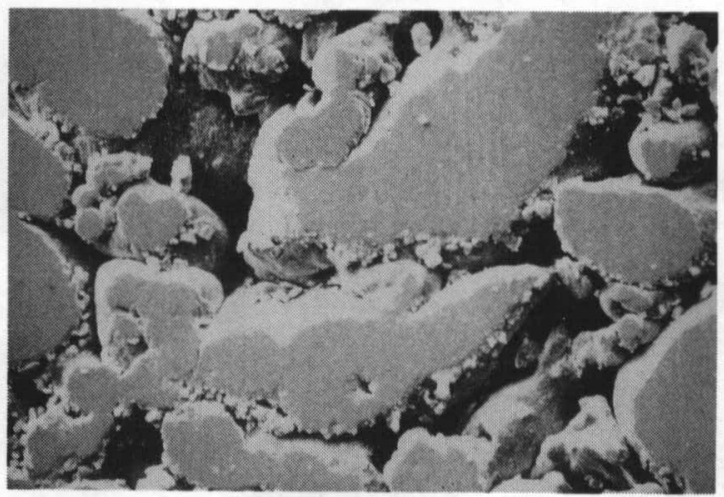

(d) Die side, 2nd Comp.:1470MPa, M2

Fig. 6 Side surfaces of green compacts of $300 \mathrm{M}$ and $\mathrm{M} 2$ on various compacting pressures. $\overline{25 \mu \mathrm{m}}$

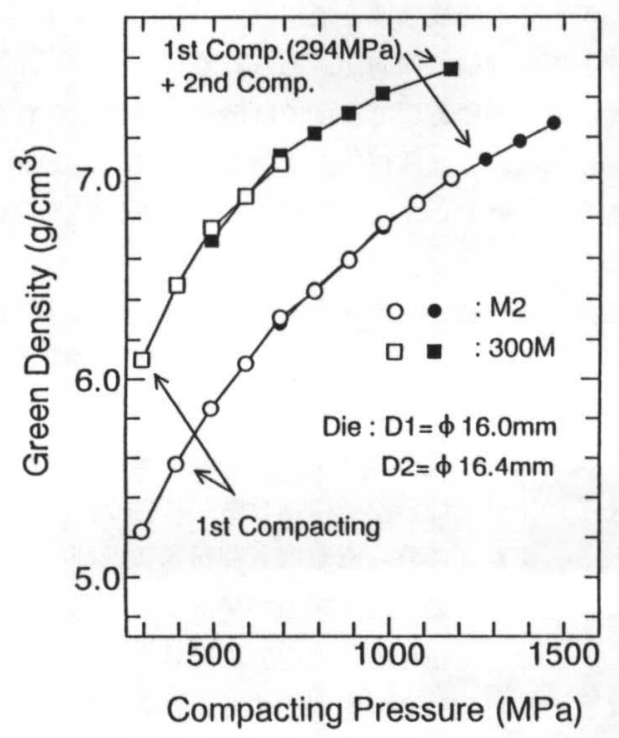

Fig.7 Effect of compacting pressure on green density of $300 \mathrm{M}$ and $\mathrm{M} 2$ powder.
Fig. 6に圧粉体の金型との摺動而およびコアと接した 面のSEM像を示す. $300 \mathrm{M}$ 粉の 1 回成形における代力 686 MPaの圧粉体表面（a)ではほぼ全面に䓎付痕”が激しく， 気孔も非常に少ない，同一圧粉体のコアに接する表而 (b)は报出しの際に圧力下での摺動を受けないので粉 末形状が明確に認められる。このことからも 1 回成形 に用いた金型のように抜出し将の摺動距離が長くなる と粉末と金型との焼付を起こし易くなることが示唆さ れる。これと比較して，2 回成形における圧力 $784 \mathrm{MPa}$ の場合の金型之接する圧粉体表陑（c）は成形王力が高 いにもかかわらず良好な面をしている。これは 2 回成 形における金型潤滑が 2 回となった影箱と考えられる。

同様にM2粉における成形圧力 $1470 M P a の$ 場合の金型壁 に接する面のSEM像（d)は元の粒.子が明確であり,メ夕 ルフローも少なく、気孔部には高圧成形により生じた 䋱かい金属粉および閵滑剂が認められる。このように M2粉は高圧成形においても爟付難いことから，さらに 高压の成形の可能性もある. 


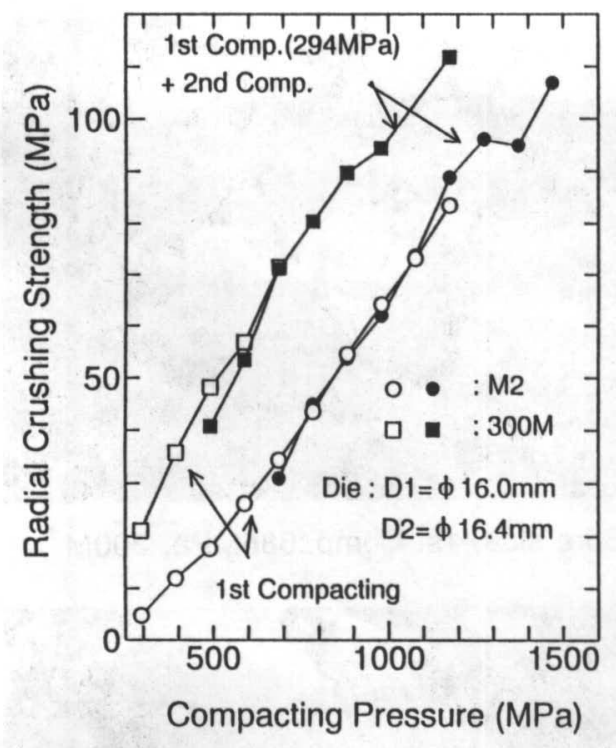

Fig.8 Effect of compacting pressure on radial crushing strength of green compacts.

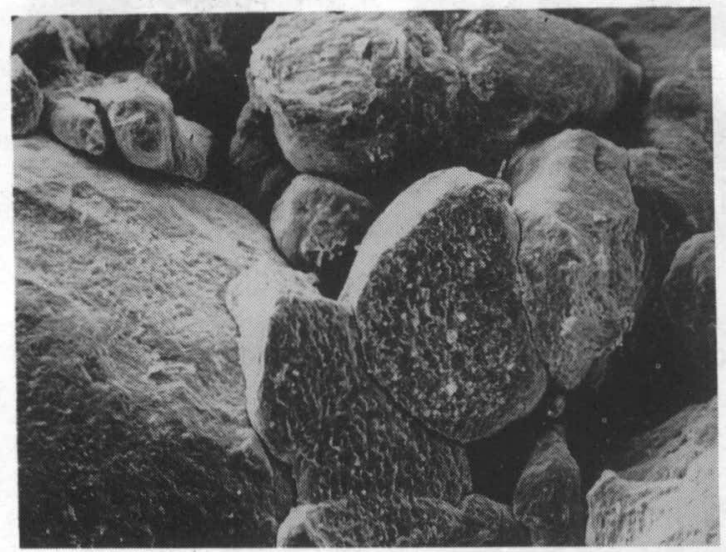

(a) $\overline{10 \mu \mathrm{m}}$

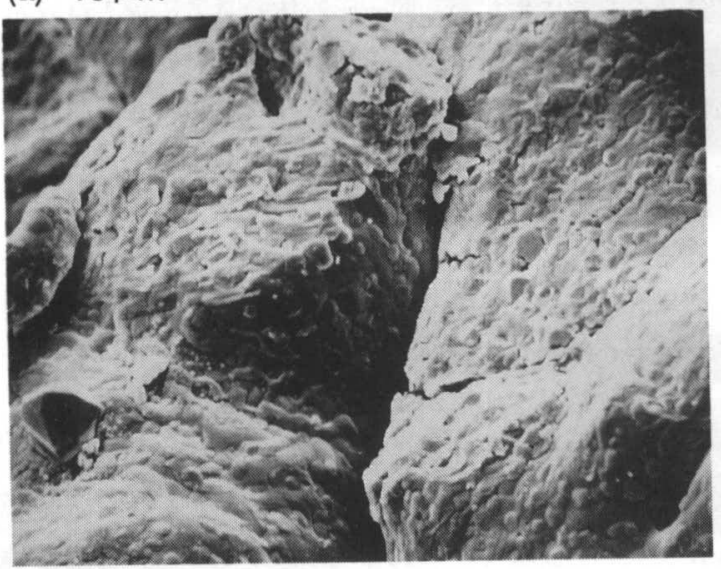

(b) $5 \mu \mathrm{m}$

Fig.9 Fracture surface of $\mathrm{M} 2$ green compacts at 2nd compacting pressure of $1470 \mathrm{MPa}$.

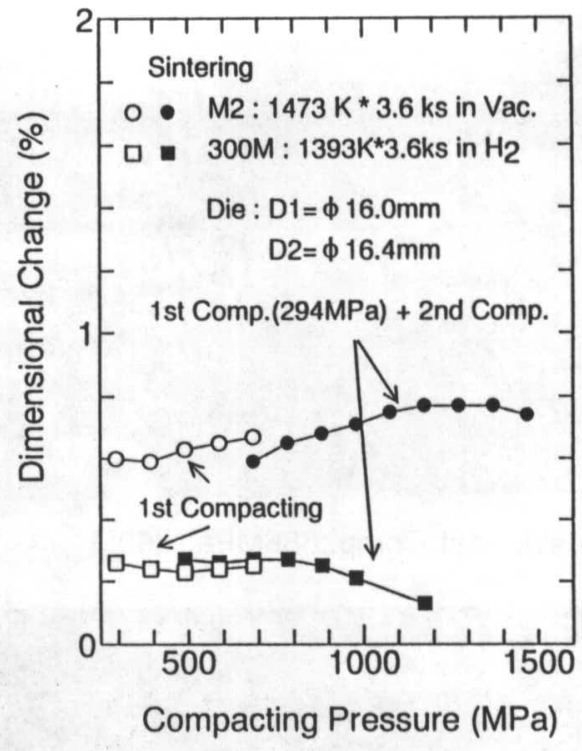

Fig.10 Effect of compacting pressure on dimensional change of $300 \mathrm{M}$ and M2 powder.

\section{3 高圧成形における圧粉体特性}

両粉末束の成形圧を上げた場合の圧粉体密度をFig. 7に 示す.いずれも成形方法による密度の差は認められず， 両粉末とも高圧成形侧で飽和傾向が現れているが，密 度上昇が得られている，2回成形において，3000粉お よびM2粉ではそれぞれ圧粉体密度 $7.54 \mathrm{~g} / \mathrm{cm}^{3}$ (成形压 力: $1176 \mathrm{MPa}$ )， $7.27 \mathrm{~g} / \mathrm{cm}^{3}$ (成形圧力: $1470 \mathrm{MPa}$ )を 得た。

次に圧粉体の圧環強度と成形圧力の関係(Fig. 8)は圧 粉密度とほぼ同様の傾向が認められる。しかし，300M 粉の高圧成形侧において密度では飽和傾向が見られた が，圧粉体強度では成形圧力に対して直線的に上昇し ている、M2粉においても同じ勾配で強度上昇が見られ る.

圧環強度試験後の圧粉体破面をFig. 9に示す.M2粉の 成形圧力1470MPaの場合で，(a)においては左侧の大き な粒子に比較的大きな面積の圧着痕が見られ，中央の 小さな粒子においても大きな変形応力を受けているの が伺える.中央上部の粒子には緻密化に伴う滑り痕が 見られる.また，これら圧着痕もM2粉末に微絒均一分 散した炭化物の影響で粒子表面が平祮でなく機械的な 絡み合いにより区粉体の強度向上に有効之考えられる。 さらに拡大した破面（b)を観察すると，右侧粒子表面 に皂裂が認められ, 高圧成形では粒子の変形が粒子の 破壊をもたらした。これらの変形にともない粒子間に "ずれ”が生じ，その滑り痕と思われるものが左側粒 


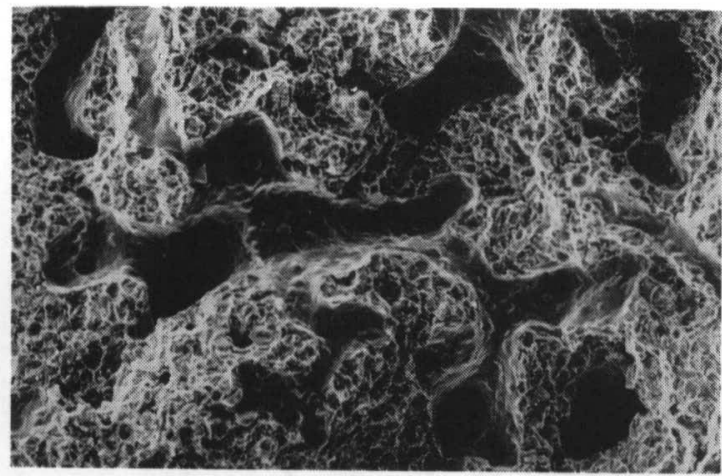

Fig.11 Effect of compacting pressure on radial crushing strength of M2 sintered compact.

子の上部に観察される。このように，わずかな粒子間 のずれにより粒子同士の圧着の程度が向上し, 圧粉体 強度が密度上昇が鈍ったにもかかわらず増加したもの と考えられる。

\section{4 M 2 粉の固相焼結}

各成形体をそれぞれの粉末の焼結条件で焼結した場 合の寸法変化をFig. 10に示す. 300以成形体については $0.2 \%$ 位の寸法収縮でほぼ一定の值を示し, 高圧侧で圧 粉体密度が高い分わずかに減少している，M2成形体に おいては成形圧力の增加にともないわずかに収縮が大 きくなっているが，0.7\%付近で安定している．このよ うにM2粉は300M粉より，固相焼結においても焼結性が 良好である。また，Fig. 3に示した液相焼結による適正 条件の寸法变化の $1 / 7$ 程度で, 通常の鉄系機械部品の $\mathrm{F}$ $e-2.5 \%$ Cuの寸法変化 ${ }^{11}$ ) $0.8 \%$ に敵し，十分な寸法精 度が得られる。

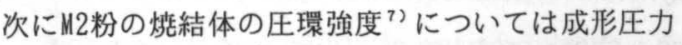
とほとんど比例して増加し，成形圧力1470MPaにおいて 圧環強度1687MPaが得られた。このように圧粉体密度と 成形压の関係(Fig. 7) と異なり, 直線的に強度が上昇し ていることから，さらに高圧成形による強度の向上の 可能性が考えられる.ここで Fig. 11 に 2 回目の成形 圧力 $1372 \mathrm{MPa}$ の場合の焼結体の破面の走查電子顕微鏡 钼察結果を示す. 破断面は元の粉末の細かい炭化物の 分散状態が保持され, 粗大な気孔も無く, 形状もかな り球状化しているのが分かる.

\section{4 結言}

水アトマイズ高速度鋼粉末の利用するにあたり、金 型成形性は良好であることに着目し機械部品等への応 用を前提とした。しかし, 焼結の際に液相烓結を利用 すると焼結温度に做感で特性ばらつきが大きく, さら
に寸法精度が腎い焺結操作上の問題点がある．その解 決方法として固相烓結を前提として高密度化の可能性 を榆討した，得られた結果を要約すると以下のようで ある.

1) 鉄系焼結材料で用いられる成形圧力 $500 \mathrm{MPa}$ の 3 倍 まで高めるため, 2 回成形を行った。この方法におし て300M粉では金型と圧粉体の潤滑状態の改善が顕著て あり，M2粉でむ成形圧力1470MPaで良好な圧粉体を得， ことが可能となった.

2 )このような高压成形により，M2粉は300M粉より圧 粉体密度の上昇率が高く, $7.27 \mathrm{~g} / \mathrm{cm}^{3}$ が得られた。

3) M2粉は硬質粉末にもかかわらず，300M粉の成形氏 力の約 $300 \mathrm{MPa}$ 上のものと同等の圧粉体強度を示した。 さらに高圧成形侧まで成形圧に比例して強度の向上力 得られ，複雑形状などにも適応可能と考えられる。

4) 固相焼結による寸法変化は，成形圧力によらずに ぼ一定の值で液相衽結の場合の $1 / 7$ 以下であり, 寸法 度の向上が期待できる。

5 ）焼結体強度は圧粉体密度が多少館和傾向にあるに もかかわらず直線的に向上している．このことはさこ に高圧成形による特性向上を示唆している，このよ に成形圧力で焼結特性を制御できることにより，邺糸 操作は非常に容易となった。

\section{文献}

1) P. R. Brewin, D. K. Banbury: Metal Powder Report, Sept. (1983) 497.

2) R, Wahling, P. Beiss, W. J. Huppmann: powder Metal] 29(1986)53.

3) M. Igharo, J. V. Wood:Powder Metall. , 33(1990)31:

4) P. Maulik, W. J. C. Price:Powder Metall. , 30(1987; 240.

5）日本鉄鋼協会編: 第3版鉄鋼便覧, 丸普, (1982) 529 .

6) J.Asami, N. Hirose:Proceedings of 1993 Powder Metallurgy World Congress, (1993)875.

7) J.Asami, T. Aizawa:Proceedings of 1994 Powder Metallurgy World Congress, (1994)949.

8）浅見，川原：粉体および粉末治金，41(1994)139!

9) G. Bockstiegel, 0. Svensson: Powder Metall. , 12 (1969) 316 .

10) K. S. Baird, J. D. Williams: Powder Metall, , 30 (1987) 281.

11) 日本粉末冶金工業会編: 焼結機械部品, 技術書院 (1987)97. 